\title{
Changes in Organization at Columbia
}

Dr. Logsdon is director of libraries, Columbia University.

$\mathrm{T}$ HE DESCRIPTION GIVEN BELOW of changes in organization and division of responsibility within the Columbia University Libraries which went into effect July I, I 953 is taken directly from the "Bulletin" issued to the staff at that time. Present organization is shown on the accompanying organization chart.

The Position of Associate Director Discontinued. The duties and responsibilities of the positions of Director and Associate Director will be carried by the now full time position of Director and by the Assistant Director and Supervising Librarians. Division of responsibility within the Office of the Director of Libraries will be presented in more detail later in this statement.

Assistant Director of Technical Services now Assistant Director. The Assistant Director Technical Services will drop the Technical Services part of his title, devoting full time to sharing the work of the Office of the Director of Libraries, including full responsibility in the absence of the Director.

The Catalog Librarian will report to The Director of Libraries rather than to the Assistant Director, Technical Services, as previously. Administrative units within the Cataloging Division remain the same, i.e. (I) General Cataloging; (2) Serials Cataloging; (3) Processing; (4) Law Cataloging; (5) Medical Cataloging.

The Scope of the Acquisitions DePARTMENT IS ENLARGED TO INCLUdE Binding and Photographic Services. The acquisitions Librarian will have general re- sponsibility for the work of the Acquisitions Department as now constituted, the Binding Department, and the Department of Photographic Services. Accordingly, there will be five units in this newly constituted division, namely ( I) Book Order Division; (2) Gifts and Exchanges; (3) Serials and Documents Acquisitions; (4) Binding; (5) Photographic Services. The Acquisitions Librarian will report to the Director of Libraries.

The Library of the School of LIBRARy Service IS Now Part of the Division of Special Collections, having been transferred from the Butler Division. This was done for three reasons: (a) the close relationship between Special Collections and the School of Library Service Library in their concern with and coverage of the Graphic Arts and Book Arts material; (b) the close geographical location and joint use of Deck 12 of the stacks; (c) a desire to utilize more fully the space presently assigned to Special Collections and the $\mathrm{Li}$ brary School Library.

Other changes in the Butler DiviSION. The responsibilities of the College Librarian will be enlarged to include general supervisory responsibility for the Philosophy Library and Lending Service. The bases for this change were three: (a) to achieve a more even distribution of responsibility within the Butler Division; (b) the adjacent physical location; (c) to provide greater flexibility in the use of staff assigned, particularly during vacation and intersession periods.

Four Readers' Services Divisions CONTINUE WITH THE SAME INTERNAL ORganization. The four remaining divisions 
Columbia University Libraries Organization Chart juily I, 1953

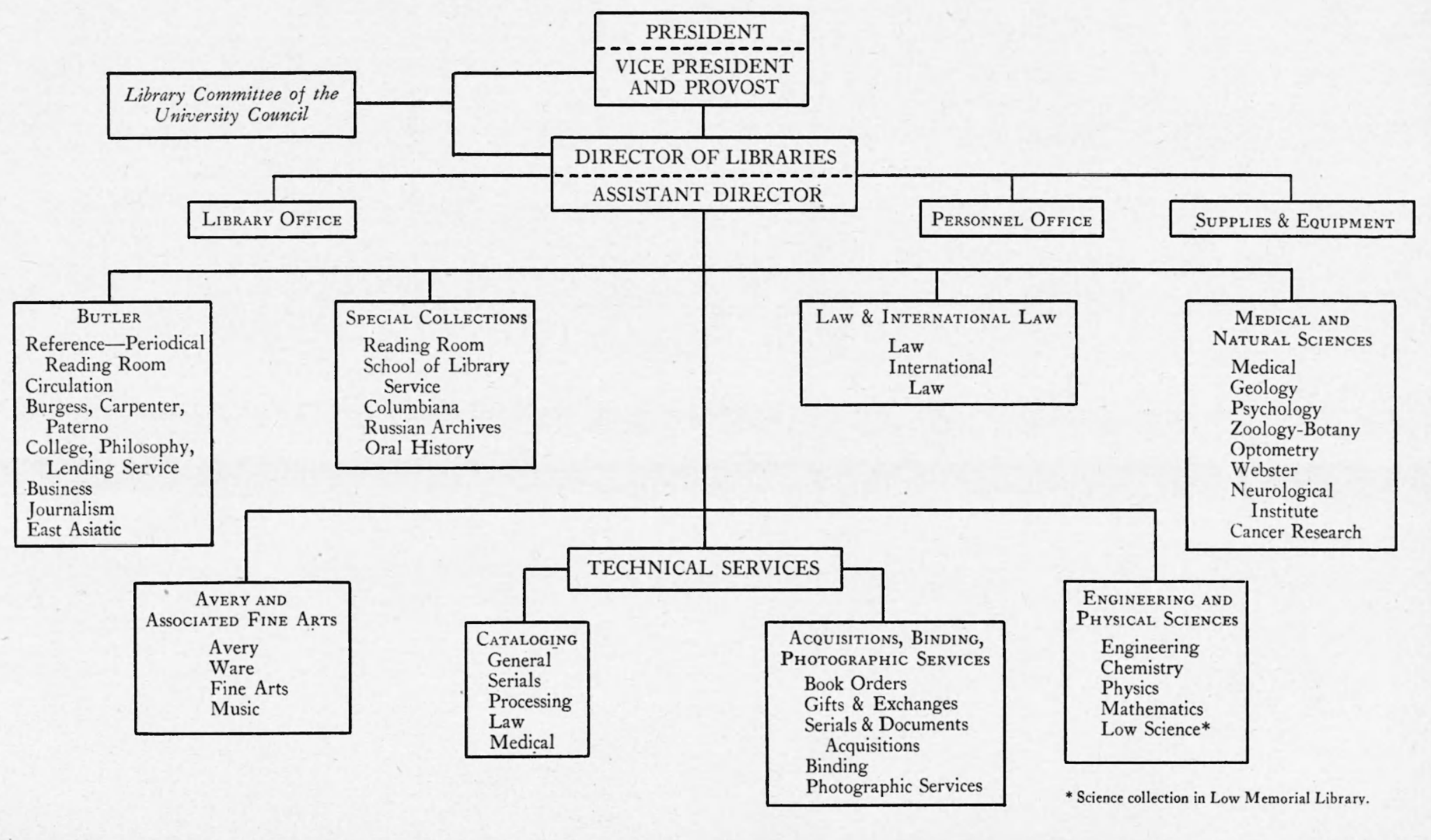


of the Readers' Services, namely ( I ) AveryWare and associated Fine Arts Libraries; (2) Engineering and Physical Sciences Libraries; (3) Law and International Law Libraries; (4) Medical and Natural Sciences Libraries will continue to operate on the Divisional arrangement as heretofore.

Research and Studies Assistant becomes Administrative Assistant. The position of Research and Studies Assistant established in 1948 has been renamed Administrative Assistant. The scope of this position will include research and studies projects, general supervision of the Library Office, and assistance in work related to the Development Program.

The Personnel Officer and the Supply and Equipment Clerk continue with the same responsibilities, reporting to the Assistant Director.

DIVISION OF RESPONSIBILITY WITHIN the Office of the Director of LiBRARIES. The Director of Libraries will work directly with the eight Supervising Librarians, the Assistant Director, and Administrative Assistant in planning and carrying out the work of the University $\mathrm{Li}$ braries. This position will carry primary responsibility for liaison with the Office of the President of the University, the Library Committee, the University Council, and with Faculties or members of the Faculties where questions coming from the latter involve more than one division of the library. It will also carry responsibility for preparation of the annual budget and for any changes in individual allocations covered by the budget.

The Assistant Director will carry primary responsibility for work relating to (I) the Controller of the University; (2) the Department of Buildings-and Grounds; (3) the Office of Public Information; (4) personnel policies of the University with special reference to Non-Academic Personnel Com- mittee; (5) the Purchasing Agent of the University; (6) interpretation of personnel policies of the libraries and the University: (7) Friends projects and activities, including Columbia Library Columns.

Flexibility will be the keynote in handling responsibility within the Director's Office, adjusting work between Director and Assistant Director as circumstances dictate during the year, and especially in handling representation with outside groups.

General Comment. In making these changes, it is recognized that there is no one perfect organization for all time but rather a choice of more promising alternatives at a given time. No feature of our organization and way of operating should be considered as permanent. If something fails to work out well in practice, we should change quickly to something better.

Guide lines in developing the above proposals were (I) to retain the strength of past experience and practice especially in building up divisional responsibility; (2) to strive for a maximum of direct communication-that is, a relatively horizontal as opposed to a vertical organization; (3) to provide for the maximum of autonomy of operation in divisions and departments, consistent with the objectives of a co-ordinated library system; (4) to secure a maximum of staff participation in developing and maintaining the library program.

"Administration" of the Libraries will be considered as residing with the Supervising Librarians, the Assistant Director and Director, as influenced by recommendations of Department Heads. Monthly meetings of the Supervising Librarians are projected, as have been held in the past, with something like quarterly meetings of Department Heads and Supervising Librarians.

These features are not new but are mentioned here to indicate that continued and increasing emphasis is being given to them. 